\title{
EWSR1/PATZ1 Fusion Gene
}

National Cancer Institute

\section{Source}

National Cancer Institute. EWSR1/PATZ1 Fusion Gene. NCI Thesaurus. Code C99238.

A fusion gene that results from a chromosomal inversion inv(22)(q12q12) which fuses the first eight exons of the EWSR1 gene with the PATZ1 gene. This rearrangement is associated with Ewing tumor/peripheral primitive neuroectodermal tumor. 